medRxiv preprint doi: https://doi.org/10.1101/2021.08.16.21262069; this version posted August 23, 2021. The copyright holder for this preprint (which was not certified by peer review) is the author/funder, who has granted medRxiv a license to display the preprint in It is made available under a CC-BY-NC-ND 4.0 International license.

\title{
Reduced $T$ cell and antibody responses to inactivated coronavirus vaccine among males and individuals above 55 years old
}

Running title: Reduced immunogenicity of Coronavac in the elderly

Medeiros, G.X. ${ }^{1,2}$, Sasahara, G.L. ${ }^{1,2}$, Magawa, J.Y ${ }^{1,2}$, Nunes, JPS ${ }^{1,2}$, Bruno, F.R. ${ }^{1,2}$, Kuramoto, A. ${ }^{1,2}$, Almeida, R.R. ${ }^{2}$, Ferreira, M.A. ${ }^{3}$, Scagion. G.P. ${ }^{4}$, Candido, E.D. ${ }^{4}$, Leal, F.B. ${ }^{4}$, Oliveira, D.B.L. ${ }^{4,5}$, Durigon, E.L. ${ }^{4,6}$, Silva Jr., R.C.V. ${ }^{2}$, Rosa, D.S. ${ }^{5,9}$, Boscardin, S.B. ${ }^{6,9}$, Coelho, V.P.C. ${ }^{1,2,9}$, Kalil, J*1,2,9, Santos, K.S. ${ }^{* 1,2,9}$, Cunha-Neto, E. ${ }^{* 1,2,9}$

${ }_{1}$ Faculdade de Medicina da Universidade de São Paulo, Departamento de Clínica Médica, Disciplina de Alergia e Imunologia Clínica, São Paulo, SP, Brasil

${ }_{2}$ Laboratório de Imunologia, Instituto do Coração (InCor), Hospital das Clínicas da Faculdade de Medicina da Universidade de São Paulo, (HCFMUSP) São Paulo da Universidade de São Paulo, SP, Brasil

${ }_{3}$ Laboratório de Biologia Celular, LIM59, Departamento de Patologia da Faculdade de Medicina FMUSP, Universidade de São Paulo, São Paulo, Brasil.

4Departamento de Microbiologia, Instituto de Ciências Biomédicas, Universidade de

São Paulo, São Paulo, SP, Brasil.

5Instituto Israelita Albert Einstein de educação e pesquisa, São Paulo, Brasil.

${ }_{6}$ Plataforma Cientifica Pasteur Universidade de São Paulo, São Paulo, Brasil.

${ }_{7}$ Departamento de Microbiologia, Imunologia e Parasitologia, Universidade Federal de

São Paulo UNIFESP-EPM, São Paulo, SP, Brasil.

${ }_{8}$ Departamento de Parasitologia, Instituto de Ciências Biomédicas, Universidade de São Paulo, São Paulo, SP, Brasil

9Instituto de Investigação em Imunologia, Instituto Nacional de Ciências e Tecnologia, iii, INCT, Brasil.

\begin{abstract}
Background. CoronaVac is an inactivated SARS-CoV-2 vaccine that has been rolled out in several low and middle-income countries including Brazil, where it was the mainstay of the first wave of immunization of health care workers and the elderly population. We aimed to assess the $\mathrm{T}$ cell and antibody responses of vaccinees as compared to convalescent subjects. Methods. We detected IgG against SARS-CoV-2 antigens, neutralizing antibodies against the original SARS-CoV-2 strain, and used SARS-CoV-2 peptides to detect IFN-g and IL-2 specific T cell responses in a cohort of CoronaVac vaccinees $(\mathrm{N}=101)$ and convalescent $(\mathrm{N}=72)$ individuals. Findings. Among vaccinees, $95 \%$ displayed $\mathrm{T}$ cell or antibody responses to SARS-CoV-2 as compared to $99 \%$ convalescent individuals. However, we observed that among vaccinees, males and individuals 55 years or older developed significantly lower anti-RBD, anti-NP and neutralizing antibody responses as well as antigen-induced IL-2 production by T cells. Interpretation. Even though some studies indicated Coronavac helped reduce mortality among elderly people, considering the current dominance of the gamma variant of concern (VOC) and potential increase of the delta VOC, in Brazil, our data support that Coronavac vaccinees above 55 years old Coronavac vaccinees above 55 years old could benefit from a heterologous third dose/booster vaccine to improve immune response and protection. Funding: Brazilian Ministry for Science, Technology and Innovation, Sao Paulo State Foundation for Scientific research (FAPESP), JBS S.A.
\end{abstract}


medRxiv preprint doi: https://doi.org/10.1101/2021.08.16.21262069; this version posted August 23, 2021. The copyright holder for this preprint (which was not certified by peer review) is the author/funder, who has granted medRxiv a license to display the preprint in It is made available under a CC-BY-NC-ND 4.0 International license .

\section{Key words:}

COVID-19, vaccine, Coronavac, T cell responses, antibody, neutralizing antibody, age, elderly, sex, Interleukin-2, Interferon-gamma 
medRxiv preprint doi: https://doi.org/10.1101/2021.08.16.21262069; this version posted August 23, 2021. The copyright holder for this preprint (which was not certified by peer review) is the author/funder, who has granted medRxiv a license to display the preprint in It is made available under a CC-BY-NC-ND 4.0 International license .

\section{Background}

Terminating the COVID-19 pandemic is dependent on global vaccination. CoronaVac (Sinovac, China) is a vaccine based on inactivated SARS-CoV-2 that has been deployed in China, Brazil, Indonesia, Thailand, Turkey, and Chile among other countries. In Brazil, Coronavac was the mainstay of the first wave of immunization of health care workers and the elderly population. In spite of the finding of reduced COVID-19 mortality in Brazil among people above 70 or 75 years of age were registered when Coronavac was the most used vaccine, indicating protection for this group, immunogenicity of this vaccine in elderly individuals is still poorly known. ${ }^{1,2}$ Some studies reported seroconversion for up to $98 \%$ of vaccinees but anti-Spike antibody titers were significantly lower among those aged $\geq 60$ years. $^{3,4}$ The immunogenicity of inactivated vaccines such as influenza is more limited among the elderly. 5,6

MRNA-based vaccines that protect more than $90 \%$ of the vaccinated individuals from severe COVID-19 were shown to induce T cell responses. ${ }^{7}$ Although an immunogenicity study in Chile has studied cellular immunity to Coronavac, few subjects were above 60 years of age. ${ }^{8}$ In order to assess the effect of age and sex in the vaccine response of adults and elderly people, we studied the anti-SARS-CoV-2 responses of a group of 101 vaccinees (including 42 subjects above 60) as compared to COVID-19 convalescent and seronegative individuals. In this paper, we assessed $\mathrm{T}$ cell immune responses with an antigen-induced cytokine release assay on whole blood as well as both binding antibody responses (against Spike, RBD and NP) and neutralizing antibodies against the original Wuhan strain.

\section{Methods}


medRxiv preprint doi: https://doi.org/10.1101/2021.08.16.21262069; this version posted August 23, 2021. The copyright holder for this preprint (which was not certified by peer review) is the author/funder, who has granted medRxiv a license to display the preprint in It is made available under a CC-BY-NC-ND 4.0 International license .

Coronavac vaccinees $(n=101$; age range 23-90) received two doses of 3 ug vaccine/shot, 3 weeks apart. Venous blood was collected at least 28 days after the second immunization. Convalescent individuals ( $\mathrm{n}=72$; age range $25-68)$ with at least 160 days since the onset of the infectious episode, as well as seronegative controls ( $n=36$; age range 22-66) were also studied. All volunteers signed written informed consent and the study was approved by the Ethics Committee of the Hospital das Clinicas da Universidade de São Paulo (CAPPesq CAAE30155220.3.0000.0068).

Enzyme-linked immunosorbent assay (ELISA) was performed using 96-well highbinding half-area polystyrene plates coated overnight at $4^{\circ} \mathrm{C}$ with $4 \mu \mathrm{g} / \mathrm{mL}$ of Spike protein, $2 \mu \mathrm{g} / \mathrm{mL}$ Nucleocapsid protein (NP) (Kindly provided by Dr Ricardo Gazzinelli, UFMG, Brazil) or $0 \cdot 8 \mu \mathrm{g} / \mathrm{mL}$ of the RBD domain from SARS-CoV-2 were all expressed in HEK293T cells. ${ }^{9}$ In short, $50 \mu \mathrm{L}$ of diluted sera $(1: 100)$ were incubated at $37^{\circ} \mathrm{C}$ for 45 min. Peroxidase-conjugated goat anti-human IgG (BD Pharmingen,USA), anti-human IgA (KPL, USA) or anti-human IgM (Sigma, USA) secondary antibody conjugates were diluted $1: 10,000$, and incubated at $37^{\circ} \mathrm{C}$ for $30 \mathrm{~min}$. Values were determined as optical density (OD) minus blank and cutoff was determined as blank $+3 \mathrm{x}$ standard deviation. Results are given as the ratio of OD sample/cutoff). An antibody ratio of $\geq 1 \cdot 2$ was considered positive.

SARS-CoV-2 (GenBank: MT MT350282) was used to conduct a cytopathic effect (CPE)based virus neutralization test (VNT) as previously described. ${ }^{10}$ We used 96 -well plates containing $5 \times 10^{4}$ cells $/ \mathrm{mL}$ of Vero cells (ATCC CCL-81). A series of dilutions (1:20 to 1:2560) was prepared for the assay. Serum dilutions were mixed at equal volumes with the virus (100 tissue culture infectious doses, $100 \%$ endpoint per well - $\left.\mathrm{VNT}_{100}\right)$ and preincubated for virus neutralization for 1 hour at $37^{\circ} \mathrm{C}$. The mixtures containing serum and virus were transferred onto the confluent cell monolayer and incubated at $5 \% \mathrm{CO}_{2}$ for 
medRxiv preprint doi: https://doi.org/10.1101/2021.08.16.21262069; this version posted August 23, 2021. The copyright holder for this preprint (which was not certified by peer review) is the author/funder, who has granted medRxiv a license to display the preprint in It is made available under a CC-BY-NC-ND 4.0 International license .

three days at $37^{\circ} \mathrm{C}$, all the procedures were conducted in a Biosafety laboratory level three (BSL3). After 72 hours, plates were analyzed by light microscopy. Gross CPE was observed on Vero cells, distinguishing the presence/absence of CPE-VNT. To determine neutralizing antibody titers, the highest serum dilution that was able to neutralize virus growth was considered. As positive control, a reference serum from a RT-qPCR positive individual and a plaque reduction in the neutralization test $>640$ was used in each assay. Antigen-induced T cell cytokine release assays were performed by incubating $250 \mu 1 /$ well of heparinized peripheral blood onto round-bottom 96 well plates for $48 \mathrm{~h}$ at a humidified, $37^{\circ} \mathrm{C}, 5 \% \mathrm{CO} 2$ environment in the presence of 20 pooled $\mathrm{CD} 4+\mathrm{T}$ cell epitopes. Blood samples were kept at $4^{\circ} \mathrm{C}$ for $16 \mathrm{~h}$, and rewarmed at $37^{\circ} \mathrm{C}$ for $1 \mathrm{~h}$, prior to plating. The 20 CD4+ $\mathrm{T}$ cell epitopes used as antigen-specific $\mathrm{T}$ cell stimulus were bioinformatically identified and synthesized by scanning the whole proteome in SARS-CoV-2 reference genome (RefSeq: NC_045512.2) using the promiscuous HLA-DR binding peptide approach. ${ }^{11}$ Plates were centrifuged and plasma supernatant was harvested and stored at $-80^{\circ} \mathrm{C}$ until use. IFN- $\gamma$ and IL-2 levels in cell-free culture supernatants were evaluated by ELISA, according to manufacturer's instructions (R\&D Systems, Minneapolis, MN). Cytokine values were subtracted from the DMSO control. The quantification limit of the IFN- $\gamma$ test was $1.17 \mathrm{pg} / \mathrm{mL}$ and $0.98 \mathrm{pg} / \mathrm{mL}$ for IL-2.

Statistical analyses were performed using GraphPad Prism version 9 and a p-value $<0.05$ was considered statistically significant. Continuous variables were analyzed using Kruskal-Wallis test with Dunn's post-hoc test for multiple comparisons when three or more groups were compared, or Mann-Whitney test when two groups were compared. Feature age was clustered using the non-hierarchical K-means algorithm considering humoral or cellular responses. 
medRxiv preprint doi: https://doi.org/10.1101/2021.08.16.21262069; this version posted August 23, 2021. The copyright holder for this preprint (which was not certified by peer review) is the author/funder, who has granted medRxiv a license to display the preprint in It is made available under a CC-BY-NC-ND 4.0 International license .

\section{Results}

The subject groups and assays are described in Supplemental Table I. Among vaccinees, 95\% displayed antigen-induced cellular cytokine and/or antibody responses to at least one antigen tested, while $99 \%$ of convalescent subjects displayed cellular or antibody responses. Of interest, subjects displaying both cellular and humoral responses were 59 and 70\%, among vaccinees and convalescent individuals respectively (Fig. 1A). Vaccinated and convalescent individuals displayed significantly higher antibody and $\mathrm{T}$ cell responses than unexposed individuals. Vaccinated individuals displayed significantly reduced IgG responses against Spike protein, but increased responses against the RBD domain as compared with convalescent subjects, while responses to NP were similar between those two groups (Fig. 1B).

Regarding $\mathrm{T}$ cell responses as measured by cytokine release after peptide stimulation, we observed that IL-2 levels were higher among the convalescent as compared to the vaccinated group, and both were higher than the unexposed group, while IFN-gamma levels were similarly increased among vaccinees and convalescent subjects (Fig. 1C). GMT of neutralization titers for the 55 and older group were 6 times lower among vaccinees as compared to convalescent patients, while there was no significant difference between convalescent and vaccinated groups $<55$ yo. (Fig. 1D).

Most immune response levels were positively correlated among each other, as previously reported, ${ }^{12}$ except for NP and Spike (Fig. 2). Neutralization titers positively correlated with IgG levels for the three antigens tested and also with IFN-g and IL-2 production upon whole blood stimulation (Fig. 3). Among vaccinees, we observed significant negative correlations between age and anti-Spike, anti-RBD and anti-NP IgG antibody levels as well as IL-2 cytokine release (Fig. 4). The identification of clusters from the 
medRxiv preprint doi: https://doi.org/10.1101/2021.08.16.21262069; this version posted August 23, 2021. The copyright holder for this preprint (which was not certified by peer review) is the author/funder, who has granted medRxiv a license to display the preprint in It is made available under a CC-BY-NC-ND 4.0 International license .

numerical variables allowed us to identify the age of $\sim 55$ years as the best divisor. Therefore, we compared the two age groups: under 55 with 55 and older.

While $94 \%$ of the female vaccinees $\geq 55$ displayed antibody or $\mathrm{T}$ cell responses, only $83 \%$ of male subjects displayed any detectable responses $(p<0 \cdot 01$, Fisher's exact test). Moreover, whilst $60 \%$ of females $\geq 55$ displayed antibody and T cell responses, only $28 \%$ of men in the same age group presented both types of response simultaneously $(\mathrm{p}<0 \cdot 01$, Fisher's exact test). Antibody responses alone were observed in $39 \%$ vs $31 \%$ of male and female vaccinees $\geq 55(\mathrm{p}<0 \cdot 001)$, respectively, and cellular responses in the absence of detectable IgG was found among $17 \%$ male and $3 \%$ female vaccinees $\geq 55$ years old (Fig. 5A). Similar results were observed when we assessed neutralizing antibody and $\mathrm{T}$ cell cytokine production (Fig. 6).

Antibody responses for male vaccinees $\geq 55$ years old displayed the lowest levels of antiSpike, anti- RBD and anti-NP IgG and IL-2 release. Female vaccinees $\geq 55$ years old also showed lower anti-RBD IgG and IL-2 release than younger females (Fig. 5B). Likewise, we observed $3 \cdot 6$-fold lower GMT neutralization titers in the vaccinee group $\geq 55$ years old as compared with the younger group (Fig. 5C). GMT neutralization titers against the Wuhan strain were 3 -fold lower for vaccinees $\geq 55$ than the younger vaccinees.

\section{Discussion}

Coronavac was the first anti-COVID vaccine available for mass immunization in Brazil, where it followed schedules targeting first the healthcare workers and the elderly population. In our study, the majority of studied vaccinees developed some kind of immune response to the vaccine and the magnitude of most of the immune response measures positively correlated with each other. However, we observed a negative correlation between age and SARS-CoV-2-peptide epitopes antigen-induced IL-2 release 
medRxiv preprint doi: https://doi.org/10.1101/2021.08.16.21262069; this version posted August 23, 2021. The copyright holder for this preprint (which was not certified by peer review) is the author/funder, who has granted medRxiv a license to display the preprint in It is made available under a CC-BY-NC-ND 4.0 International license .

as well as antibody responses to Spike, RBD and NP, suggesting and immunogenicity decrease in older individuals. Upon stratification by age and sex, we observed that most of this reduced immunogenicity was due to the $\geq 55$ yo male population. Specifically, the proportion of individuals who displayed any response to the vaccine varied from $100 \%$ among younger females ( $<55$ years old) to $83 \%$ among males 55 or older. Significantly, the simultaneous detection of antibody and cellular immune responses, the ideal situation, varied from $71 \%$ among females younger than 55 years old to only $28 \%$ among males 55 or older. This suggests that the immunogenicity of the vaccine regimen is less pronounced in this age and sex group. Indeed, interleukin-2 is produced by central memory $\mathrm{T}$ cells and is essential for the development of T cell memory. ${ }^{13}$

COVID-19 immunogenicity across young and elderly patients has been studied for other vaccines. For ChadOx1, no differences were found following the second dose either for anti-Spike IgG and neutralizing antibodies or for IFN- $\gamma$ and IL-2 Th1 T cell responses among the $18-55,55-69$ and $\geq 70$ groups. ${ }^{14,15}$ A study between mRNA-1273 vaccine recipient groups of 56-70 or $\geq 71$ years of age revealed that binding, neutralizing-antibody and IFN- $\gamma$ and IL-2 responses were similar to those previously reported among vaccine recipients between the ages of 18 and 55 years and were above the median of a panel of controls who had donated convalescent serum. ${ }^{7}$ In another study, responses against the Pfizer BNT162b1 among Chinese subjects aged 18-55 and 65-85 years of age showed similar IgG and somewhat lower neutralizing antibody and a more variable $\mathrm{T}$ cell response than younger individuals. ${ }^{16} \mathrm{~T}$ cell and antibody immune responses of the elderly groups after mRNA or adenovirus vector vaccines were thus found to be largely similar to those of younger individuals, which is in contrast with observations in our cohort of inactivated virus-based Coronavac vaccinees. In our study, we used a whole blood IFN$\gamma$ and IL-2 release assay, while the cited studies used ELISPOT and flow cytometry 
medRxiv preprint doi: https://doi.org/10.1101/2021.08.16.21262069; this version posted August 23, 2021. The copyright holder for this preprint (which was not certified by peer review) is the author/funder, who has granted medRxiv a license to display the preprint in It is made available under a CC-BY-NC-ND 4.0 International license .

analysis, which in theory could be more sensitive than the whole blood cytokine release assay used here. However, IgG antibody and VNT assays were similar to those used in the previous studies and showed lower percentages among elderly individuals - especially in the male sex. This is especially relevant given the finding that Coronavac vaccinees have diminished significantly reduced neutralizing capacity against all VOCs alpha, beta and delta. ${ }^{17}$

In summary, our results show a diminished overall immune response for people older than 55 years after two-dose immunization with inactivated vaccine Coronavac. Given the finding that mixing vaccines with different platforms elicits stronger immunogenicity, our results may suggest the Coronavac vaccinees above 55 years old could benefit from a heterologous third-dose/booster vaccine. ${ }^{18}$

\section{References}

1 Victora PC, Castro PMC, Gurzenda S, Medeiros AC, França GVA, Barros PAJD. Estimating the early impact of vaccination against COVID-19 on deaths among elderly people in Brazil: Analyses of routinely-collected data on vaccine coverage and mortality. EClinicalMedicine 2021; 000.

DOI:10.1016/j.eclinm.2021.101036.

2 Alencar $\mathrm{CH}$, Cavalcanti LP de G, Almeida MM de, et al. High Effectiveness of SARS-CoV-2 Vaccines in Reducing COVID-19-Related Deaths in over 75-YearOlds, Ceará State, Brazil. Trop Med Infect Dis 2021; 6: 129.

3 Bajaj V, Gadi N, Spihlman AP, Wu SC, Choi CH, Moulton VR. Aging, Immunity, and COVID-19: How Age Influences the Host Immune Response to Coronavirus Infections? Front Physiol 2021; 11: 1-23.

4 Seyahi E, Bakhdiyarli G, Oztas M, et al. Antibody response to inactivated 
medRxiv preprint doi: https://doi.org/10.1101/2021.08.16.21262069; this version posted August 23, 2021. The copyright holder for this preprint (which was not certified by peer review) is the author/funder, who has granted medRxiv a license to display the preprint in It is made available under a CC-BY-NC-ND 4.0 International license .

COVID-19 vaccine (CoronaVac) in immune-mediated diseases: a controlled study among hospital workers and elderly. Rheumatol Int 2021; 41: 1429-40.

5 Haq K, McElhaney JE. Immunosenescence: Influenza vaccination and the elderly. Curr Opin Immunol 2014; 29: 38-42.

6 McElhaney JE, Beran J, Devaster JM, et al. AS03-adjuvanted versus nonadjuvanted inactivated trivalent influenza vaccine against seasonal influenza in elderly people: A phase 3 randomised trial. Lancet Infect Dis 2013; 13: 485-96. Anderson EJ, Rouphael NG, Widge AT, et al. Safety and Immunogenicity of SARS-CoV-2 mRNA-1273 Vaccine in Older Adults. N Engl J Med 2020; 383: $2427-38$.

8 Bueno SM, Abarca K, González PA, et al. Interim Report: Safety and Immunogenicity of an Inactivated Vaccine. 2021.

9 Oliveira JR, Machado RRG, Arcuri HA, et al. Immunodominant B cell epitope in a hotspot mutation site and mechanism of immune escape for SARS-CoV-2. medRxiv 2021; : 2021.03.11.21253399.

10 Wendel S, Kutner JM, Machado R, et al. Screening for SARS-CoV-2 antibodies in convalescent plasma in Brazil: Preliminary lessons from a voluntary convalescent donor program. Transfusion 2020; 60: 2938-51.

11 Fonseca SG, Coutinho-Silva A, Fonseca LAM, et al. Identification of novel consensus CD4 T-cell epitopes from clade B HIV-1 whole genome that are frequently recognized by HIV-1 infected patients. Aids 2006; 20: 2263-73.

12 Ni L, Ye F, Cheng ML, et al. Detection of SARS-CoV-2-Specific Humoral and Cellular Immunity in COVID-19 Convalescent Individuals. Immunity 2020; 52: 971-977.e3.

13 Dhume K, McKinstry KK. Early programming and late-acting checkpoints 
medRxiv preprint doi: https://doi.org/10.1101/2021.08.16.21262069; this version posted August 23, 2021. The copyright holder for this preprint (which was not certified by peer review) is the author/funder, who has granted medRxiv a license to display the preprint in It is made available under a CC-BY-NC-ND 4.0 International license .

governing the development of CD4 T-cell memory. Immunology 2018; 155: 5362.

14 Ramasamy MN, Minassian AM, Ewer KJ, et al. Safety and immunogenicity of ChAdOx1 nCoV-19 vaccine administered in a prime-boost regimen in young and old adults (COV002): a single-blind, randomised, controlled, phase 2/3 trial. Lancet 2020; 396: 1979-93.

15 Swanson PA, Padilla M, Hoyland W, et al. T-cell mediated immunity after AZD1222 vaccination: A polyfunctional spike-specific Th1 response with a diverse TCR repertoire. medRxiv 2020; : 1-13.

16 Li J, Hui A, Zhang X, et al. Safety and immunogenicity of the SARS-CoV-2 BNT162b1 mRNA vaccine in younger and older Chinese adults: a randomized, placebo-controlled, double-blind phase 1 study. Nat Med 2021; 27: 1062-70.

17 Vacharathit V, Aiewsakun P, Manopwisedjaroen S, et al. SARS-CoV-2 variants of concern exhibit reduced sensitivity to live-virus neutralization in sera from CoronaVac vaccinees and naturally infected COVID-19 patients. medRxiv 2021.

18 Deming ME, Lyke KE. A 'mix and match' approach to SARS-CoV-2 vaccination. Nat Med 2021; 1. DOI:10.1038/s41591-021-01463-x. 
medRxiv preprint doi: https://doi.org/10.1101/2021.08.16.21262069; this version posted August 23, 2021. The copyright holder for this preprint (which was not certified by peer review) is the author/funder, who has granted medRxiv a license to display the preprint in It is made available under a CC-BY-NC-ND 4.0 International license .

\section{Figure legends:}

Figure 1. Immune reponses comparing vaccinees and convalescents.

A: IgG and T-cell-dependent SARS-CoV-2-specific cytokine production among vaccinees and convalescent subjects.

B: IgG reactivity against SARS-COV-2 Spike protein, RBD domain and nucleocapsid protein

C: T-cell-dependent SARS-CoV-2-specific cytokine release upon whole blood stimulation with specific SARS-COV-2 peptides.

D: Viral neutralization titers grouped by age.

VNT: Virus Neutralization Titer; NP: Nucleocapsid Protein from SARS-COV-2; IFN-g: Interferon gamma. VNT below 1:20 were considered 1 in graphs, numbers above the bars show the Geometric Mean Titer (GMT), and the error bars indicate the 95\% CI.

Figure. 2. Correlations between diferente immunological parameters among vaccinees.

A: IgG for Spike protein and RBD

$\mathrm{B}$ : IgG for NP protein and RBD

$\mathrm{C}$ : IgG for NP protein and Spike protein.

D: IL-2 and IFN-g released after whole blood stimulation

E: IgG for RBD and IL-2 released after whole blood stimulation

F: IgG for RBD and IFN-g released after whole blood stimulation

G: IgG for NP and IL-2 released after whole blood stimulation

$\mathrm{H}$ : IgG for NP and IFN-g released after whole blood stimulation

NP: Nucleocapsid Protein from SARS-COV-2; IFN-g: Interferon gamma.

Figure. 3. Correlations between Viral Neutralization Titers and other immunological parameters among vaccinees.

A: VNT and T-cell responses: IFNg and IL-2 released after whole blood stimulation. B: VNT and humoral responses: IgG for Spike, RBD or NP protein.

VNT: Virus Neutralization Titer; NP: Nucleocapsid Protein from SARS-COV-2; IFN-g: Interferon gamma. VNT below1:20 were considered 1 in graphs.

Figure. 4. Correlations between age and other immunological parameters among vaccinees.

A: Age and T-cell responses: IFNg and IL-2 released after whole blood stimulation.

B: Age and humoral responses: IgG for Spike, RBD or NP protein.

NP: Nucleocapsid Protein from SARS-COV-2; IFN-g: Interferon gamma.

Figure 5. Immune responses among Coronavac vaccinees.

A: IgG and T-cell-dependent SARS-CoV-2-specific cytokine production among vaccinees. $(\mathrm{n}=101)$.

B: IgG reactivity against SARS-COV-2 Spike protein, RBD domain and nucleocapsid protein and T-cell-dependent SARS-CoV-2-specific cytokine release upon whole blood stimulation with specific SARS-COV-2 peptides grouped by age

C: Viral neutralization titers among vaccinees grouped by age and $\operatorname{sex}(n=81)$.

VNT: Virus Neutralization Titer; NP: Nucleocapsid Protein from SARS-COV-2; IFN-g: Interferon gamma. VNT below 1:20 were considered 1 in graphs, numbers above the bars show the Geometric Mean Titer (GMT), and the error bars indicate the 95\% CI. 
medRxiv preprint doi: https://doi.org/10.1101/2021.08.16.21262069; this version posted August 23, 2021. The copyright holder for this preprint (which was not certified by peer review) is the author/funder, who has granted medRxiv a license to display the preprint in It is made available under a CC-BY-NC-ND 4.0 International license .

Figure. 6. Frequency of immune responses of vaccinees considering VNT titers. Distribution of VNT and/or CK responses among vaccinees. 
medRxiv preprint doi: https://doi.org/10.1101/2021.08.16.21262069; this version posted August 23, 2021. The copyright holder for this preprint (which was not certified by peer review) is the author/funder, who has granted medRxiv a license to display the preprint in It is made available under a CC-BY-NC-ND 4.0 International license .

\begin{tabular}{|c|c|c|c|c|}
\hline & Total & $\begin{array}{c}\text { Vaccinees } \\
\text { non infected }\end{array}$ & Convalescent & Unexposed \\
\hline n & & 101 & 72 & 36 \\
\hline Age in years, mean (s.d.) & & $50.73(14.22)$ & $40(10)$ & $36(12.3)$ \\
\hline \multicolumn{5}{|l|}{ Sex, n (\%) } \\
\hline Female & & 70 (70.7) & $54(75)$ & $26(72)$ \\
\hline Male & & $31(31.31)$ & $18(25)$ & $10(28)$ \\
\hline $\begin{array}{l}\text { Time since dose } 2 \text { or } \\
\text { post symptoms onset, } \\
\text { mean days (s.d.) }\end{array}$ & - & $44(23)$ & $215(63)$ & - \\
\hline \multicolumn{5}{|l|}{$\begin{array}{l}\text { Antibody levels, mean } \\
\text { ratio (s.d.) }\end{array}$} \\
\hline IgG RBD & & $2.96(2.73)$ & $1.46(3.07)$ & - \\
\hline $\operatorname{lgG} N P$ & & $1.17(2.16)$ & $1.31(3.85)$ & - \\
\hline $\operatorname{lgG} S$ & & $1.35(2.29)$ & $3.76(5.84)$ & - \\
\hline $\begin{array}{l}\text { Neutralization titer, } \mathrm{n} \\
\text { tested; GMT }\end{array}$ & & $\mathrm{n}=81 ; 1: 22$ & $\mathrm{n}=62 ; 1: 54$ & - \\
\hline \multicolumn{5}{|l|}{$\begin{array}{l}\text { Cytokine levels, mean } \\
\text { (s.d.) }\end{array}$} \\
\hline IFN & & $2.06(19.53)$ & $3.39(13.60)$ & - \\
\hline IL-2 & & 1.21 (47.16) & 4.18 (45.61) & - \\
\hline
\end{tabular}

GMT: Geometric Mean Titer; s.d.: standard deviation 
medRxiv preprint doi: https://doi.org/10.1101/2021.08.16.21262069; this version posted August 23, 2021. The copyright holder for this preprint (which was not certified by peer review) is the author/funder, who has granted medRxiv a license to display the preprint in It is made available under a CC-BY-NC-ND 4.0 International license .

\section{FIGURE 1}

A

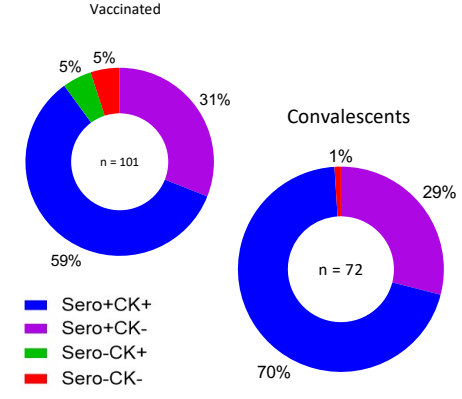

B

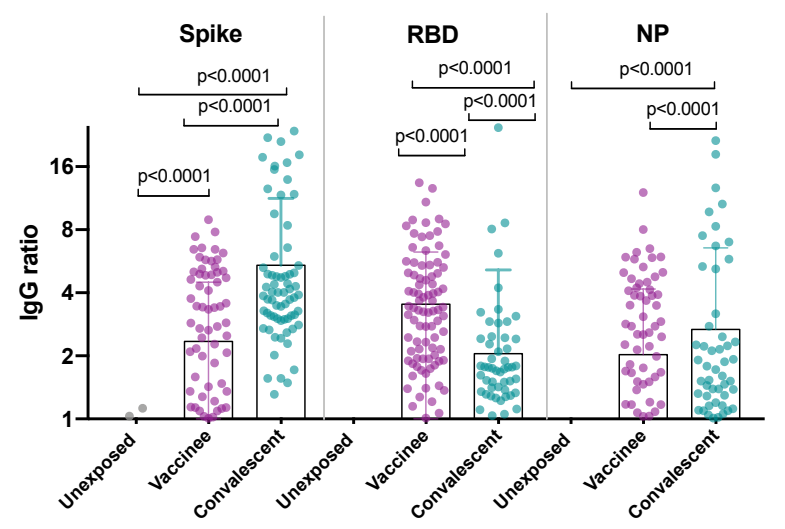

C

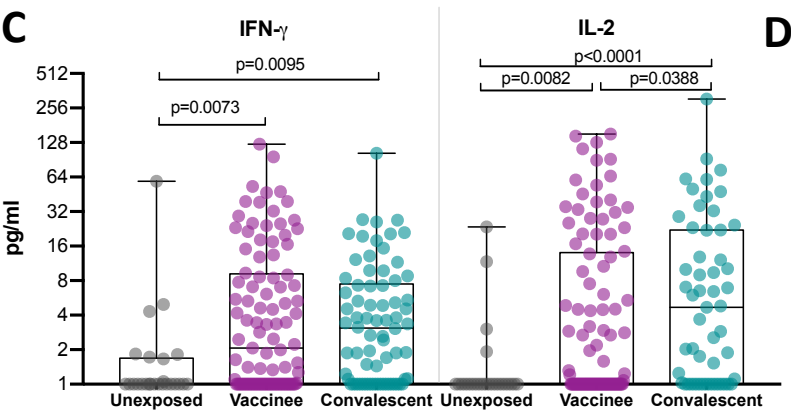

D $<55$ yo

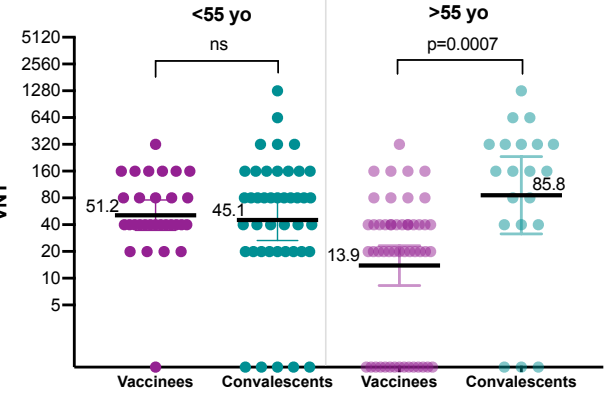


medRxiv preprint doi: https://doi.org/10.1101/2021.08.16.21262069; this version posted August 23, 2021. The copyright holder for this preprint (which was not certified by peer review) is the author/funder, who has granted medRxiv a license to display the preprint in It is made available under a CC-BY-NC-ND 4.0 International license.

\section{FIGURE 2}

A

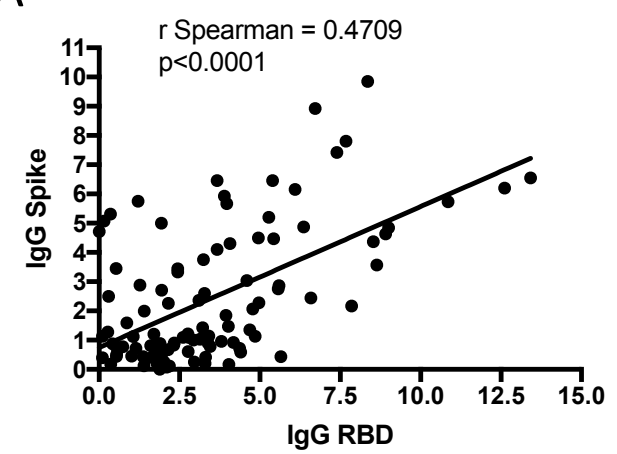

C

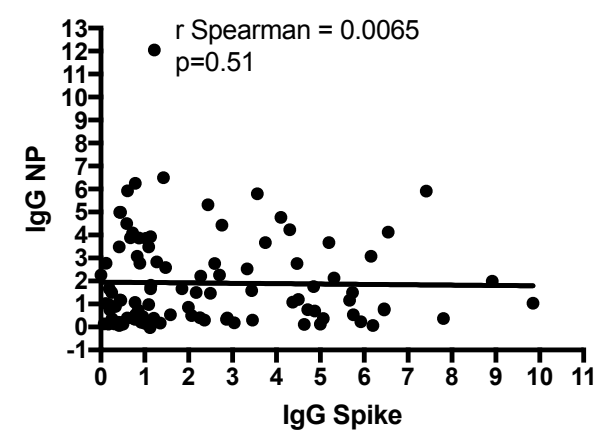

$E$

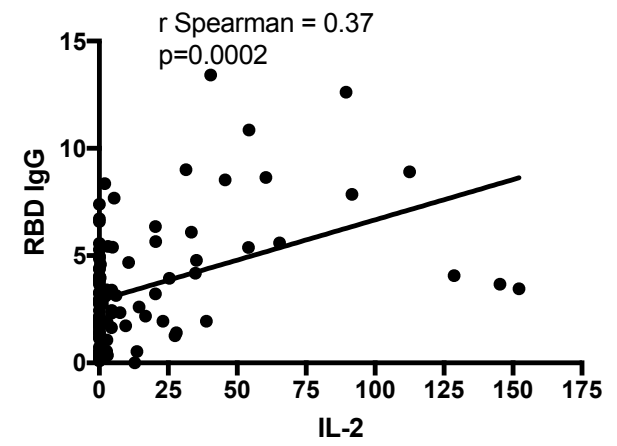

G

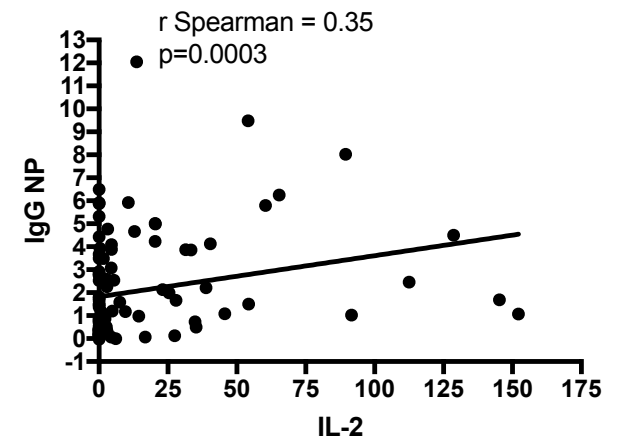

B

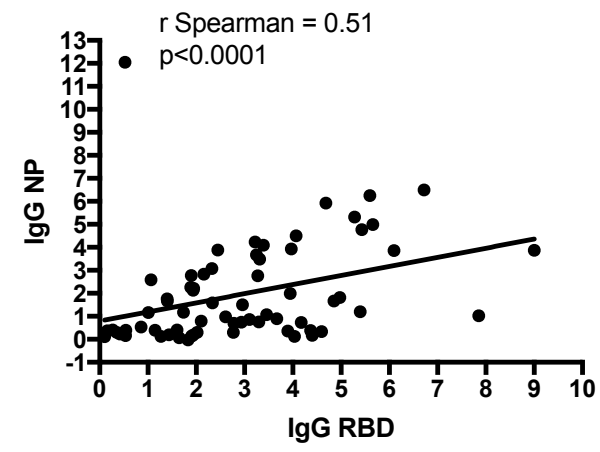

D

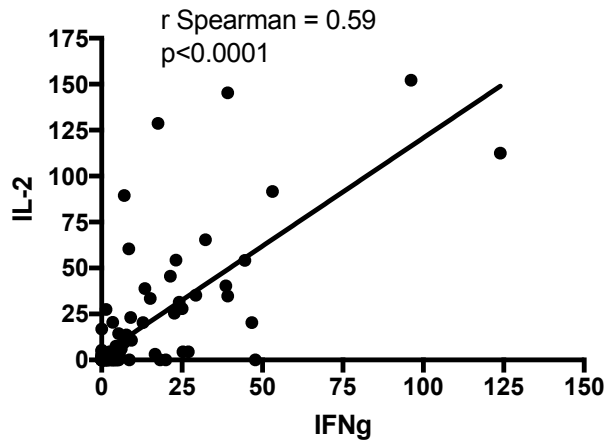

F

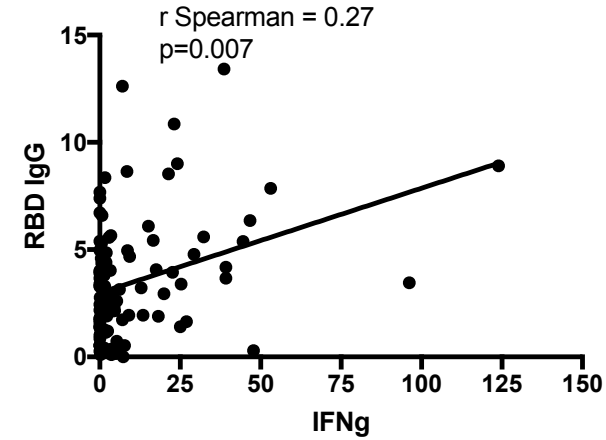

$\mathrm{H}$

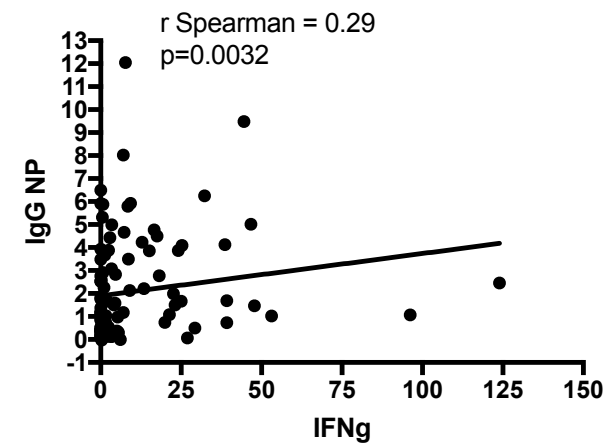


medRxiv preprint doi: https://doi.org/10.1101/2021.08.16.21262069; this version posted August 23, 2021. The copyright holder for this preprint (which was not certified by peer review) is the author/funder, who has granted medRxiv a license to display the preprint in It is made available under a CC-BY-NC-ND 4.0 International license.

\section{FIGURE 3}

A
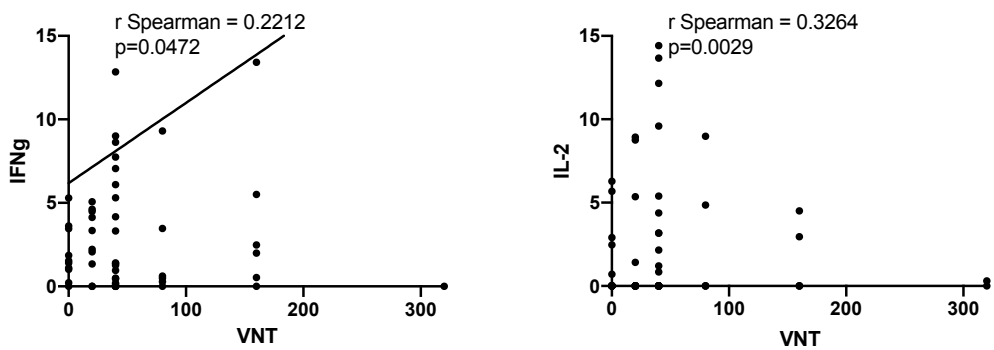

B
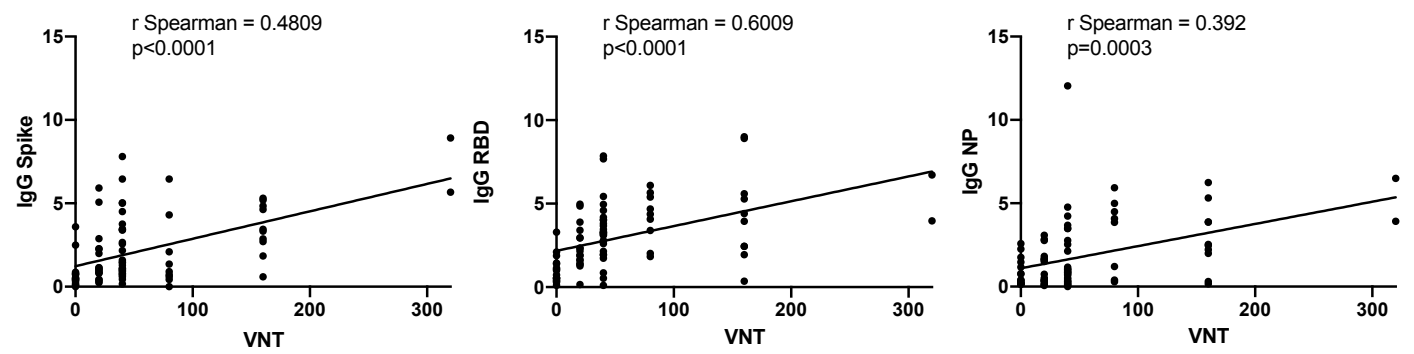

FIGURE 4

A
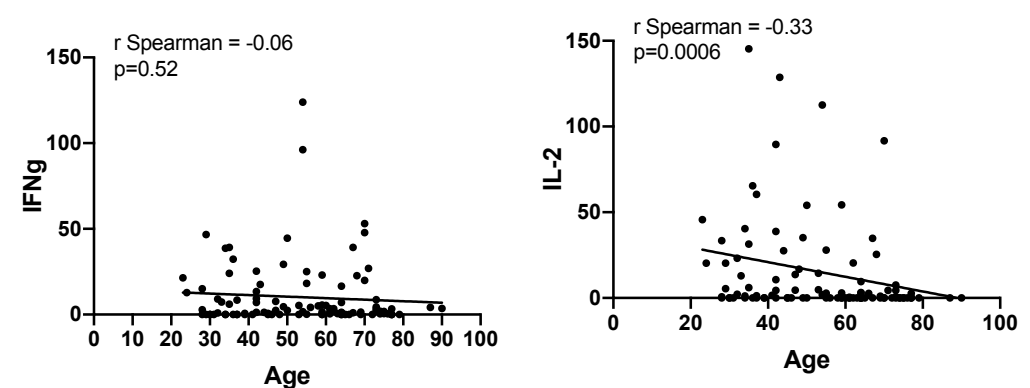

B $r$ Spearman $=-0.46$

Age
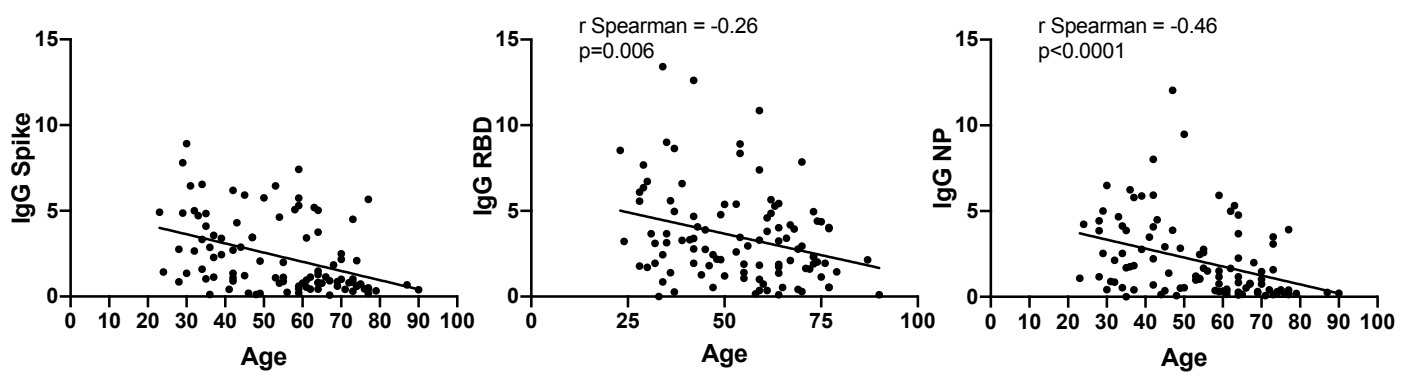
medRxiv preprint doi: https://doi.org/10.1101/2021.08.16.21262069; this version posted August 23, 2021. The copyright holder for this preprint (which was not certified by peer review) is the author/funder, who has granted medRxiv a license to display the preprint in It is made available under a CC-BY-NC-ND 4.0 International license.

\section{FIGURE 5}

B
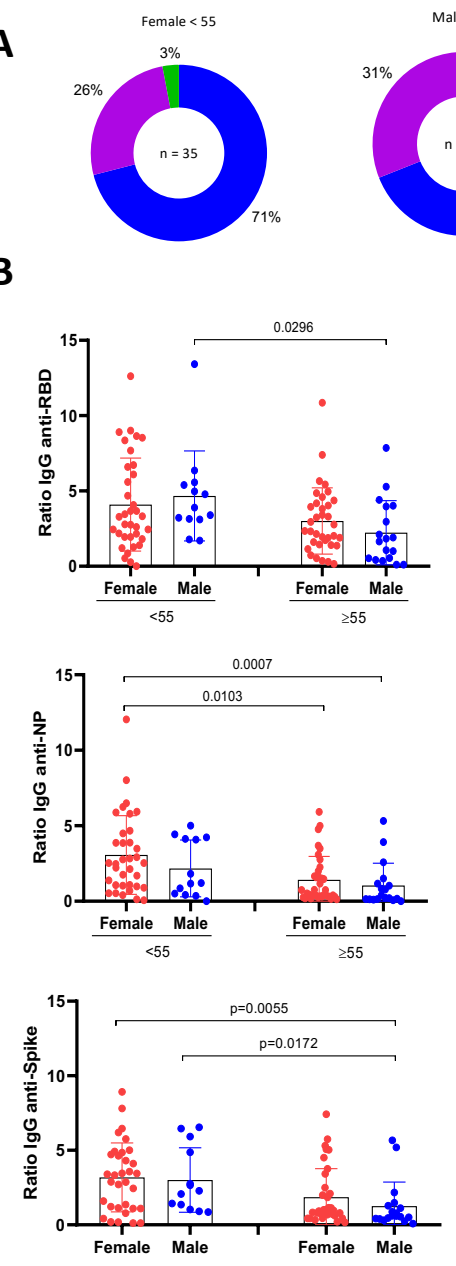
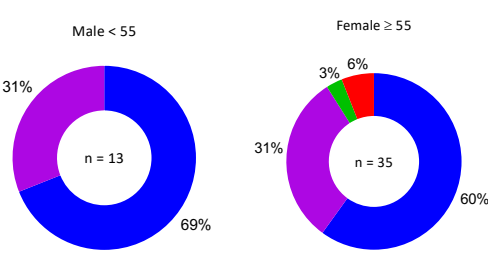

C

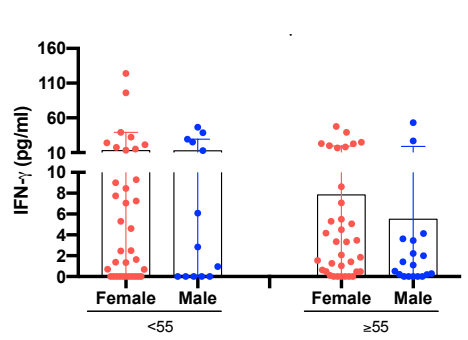

D
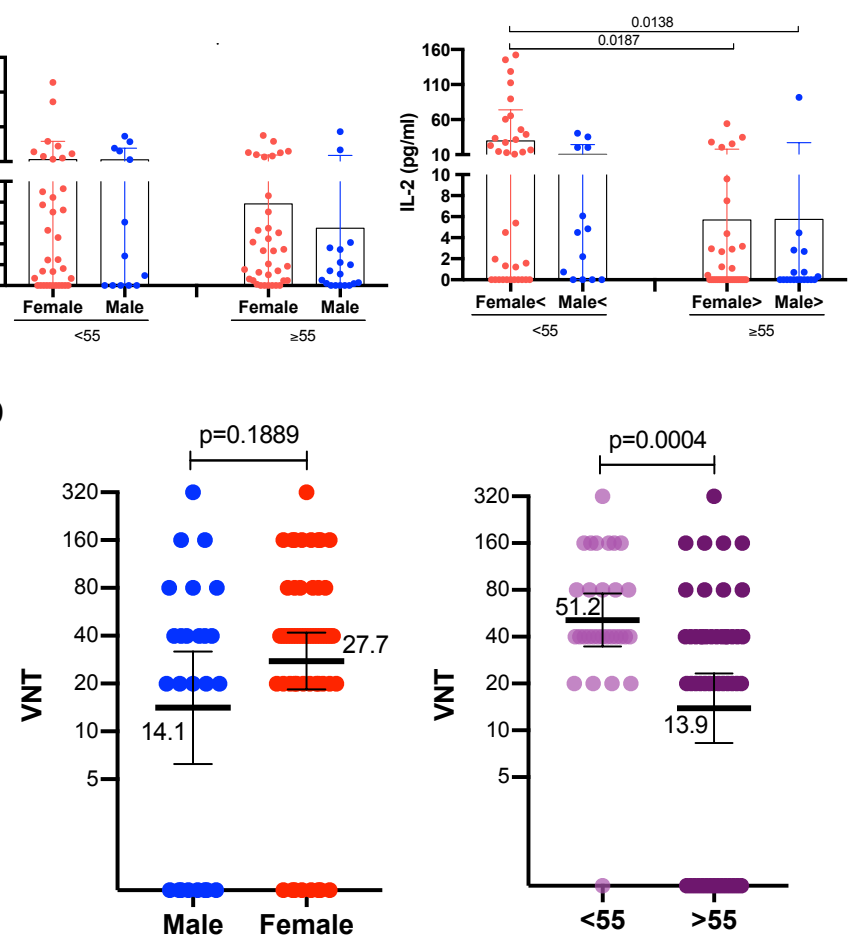

\section{FIGURE 6}

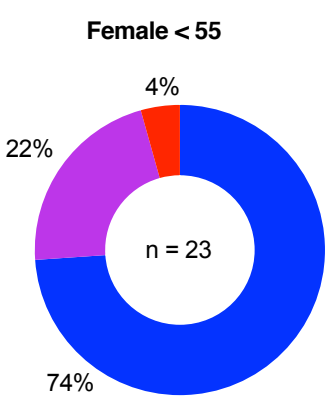

Male $<55$

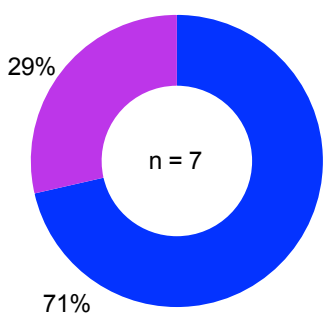

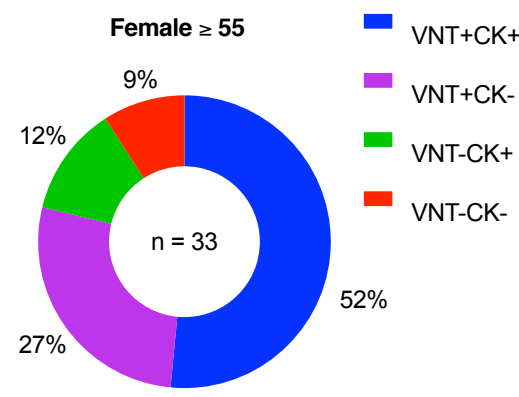

Male $\geq 55$

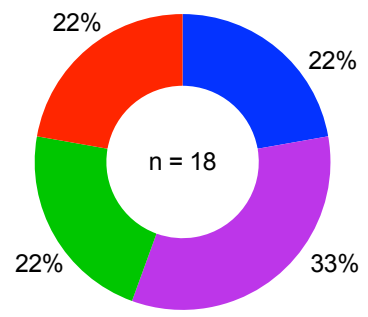

